\title{
Biochemical Evidence for a Putative Inositol 1,3,4,5-Tetrakisphosphate Receptor in the Olfactory System of Atlantic Salmon (Salmo salar)
}

\author{
Jiongdong Pang ${ }^{1,2}$ and Dennis E. Rhoads ${ }^{2,3}$ \\ ${ }^{1}$ Chemistry Department, Southern Connecticut State University, New Haven, CT 06515, USA \\ ${ }^{2}$ Department of Biochemistry, Microbiology and Molecular Genetics, University of Rhode Island, Kingston, RI 02881, USA \\ ${ }^{3}$ Department of Biology, Monmouth University, West Long Branch, NJ 07764-1898, USA
}

Correspondence should be addressed to Dennis E. Rhoads; drhoads@monmouth.edu

Received 25 September 2012; Revised 1 February 2013; Accepted 4 February 2013

Academic Editor: Mitchell T. Wallin

Copyright (C) 2013 J. Pang and D. E. Rhoads. This is an open access article distributed under the Creative Commons Attribution License, which permits unrestricted use, distribution, and reproduction in any medium, provided the original work is properly cited.

\begin{abstract}
Olfactory receptor neurons in Atlantic salmon (Salmo salar) appear to use a phosphoinositide-directed phospholipase C (PLC) in odorant signal transduction. The consequences of odor-activated PLC depend on its product, inositol 1,4,5-trisphosphate (IP $\left.{ }_{3}\right)$. Therefore, a plasma membrane rich (PMR) fraction, previously characterized from salmon olfactory rosettes, was used to study binding sites for $\mathrm{IP}_{3}$ and its phosphorylation product, inositol 1,3,4,5-tetrakisphosphate $\left(\mathrm{IP}_{4}\right)$. Binding sites for $\mathrm{IP}_{3}$ were present at the lower limit for detection in the PMR fraction but were abundant in a microsomal fraction. Binding sites for $\mathrm{IP}_{4}$ were abundant in the PMR fraction and thus colocalized in the same subcellular fraction with odorant receptors for amino acids and bile acids. Binding of $\mathrm{IP}_{4}$ was saturable and high affinity $\left(K_{d}=83 \mathrm{nM}\right)$. The rank order for potency of inhibition of $\mathrm{IP}_{4}$ by other inositol polyphosphates $\left(\mathrm{InsP}_{x}\right.$ ) followed the phosphorylation number with $\mathrm{InsP}_{6}>\mathrm{InsP}_{5}>$ other $\operatorname{InsP}_{4}$ isomers $>\mathrm{InsP}_{3}$ isomers $>\mathrm{InsP}_{2}$ isomers, with the latter showing no activity. The consequences of PLC activity in this system may be dictated in part by a putative receptor for $\mathrm{IP}_{4}$.
\end{abstract}

\section{Introduction}

Adenylyl cyclase and cAMP appear to dominate odor signal transduction in mammals (for reviews, see [1-3]). Phosphoinositides may play a divergent role in olfaction, mediating inhibitory signaling through phosphoinositide-3-kinase [4] or excitatory signaling through phospholipase $C[1,5]$. For fish, components of a phospholipase C-based olfactory signal transduction system have been characterized in catfish [6$13]$ and are seen in carp [14, 15], zebrafish [16], and Atlantic salmon $[17,18]$.

As potent olfactory stimuli for Atlantic salmon, amino acids and bile acids interact with distinct subclasses of olfactory receptors to begin the process of olfactory reception $[18,19]$. The amino acid and bile acid receptors appear to be coupled through $\mathrm{G}$ proteins to the activation of phospholipase C (PLC) and the breakdown of phosphatidylinositol 4,5bisphosphate $\left(\mathrm{PIP}_{2}\right)$ to generate diacylglycerol (DAG) and inositol 1,4,5-trisphosphate $\left(\mathrm{IP}_{3}\right)[17,18]$. Early biochemical data characterizing these as $G$ protein-coupled receptors is now supported by molecular studies characterizing olfactory receptor gene sequences from Atlantic salmon [20-23]. Underscoring the importance of these receptors in salmon physiology, odorant receptor expression has been shown to change during the parr-smolt transformation, a period characterized by increased olfactory sensitivity and olfactorybased learning [24].

The significance of olfactory PLC activity resides in part with the location and characteristics of receptors for $\mathrm{IP}_{3}$. In most cells, $\mathrm{IP}_{3}$ receptors mediate the release of $\mathrm{Ca}^{2+}$ from internal stores in the endoplasmic reticulum (for review, see [25]). However, in association with PLC-based olfactory signal transduction, $\mathrm{IP}_{3}$ receptors have been found in olfactory cilia of catfish [6], carp [14], and lobster [26, 27]. From this position, $\mathrm{IP}_{3}$ may gate $\mathrm{Ca}^{2+}$ influx through the plasma 
membrane rather than the release from intracellular stores. Another important part of $\mathrm{IP}_{3}$ signaling in other systems has been its metabolism, including phosphorylation by a 3 -kinase to generate the biologically active inositol 1,3,4,5tetrakisphosphate $\left(\mathrm{IP}_{4}\right)$ [28-30]. While $\mathrm{IP}_{4}$ continues to be studied in mammalian systems for roles as diverse as regulating nuclear calcium signaling [31], tyrosine kinase [32], and mitochondrial permeability and apoptosis [33, 34], Fadool and Ache [26] showed that olfactory receptor neurons of lobster express an $\mathrm{IP}_{4}$ receptor acting as a functional channel in the plasma membrane. In lobster, plasma membrane $\mathrm{IP}_{3}$ and $\mathrm{IP}_{4}$ receptors may interact reciprocally to regulate $\mathrm{Ca}^{2+}$ entry in olfactory neurons.

The goal of the present study was to characterize further the PLC-based olfactory signal transduction system of Atlantic salmon, beginning with the hypothesis that $\mathrm{IP}_{3}$ binding sites would colocalize with odor receptor binding sites in a plasma membrane rich fraction (PMR) that we characterized previously [17-20, 35]. Finding that binding of $\mathrm{IP}_{3}$ was marginal in this fraction, we proceeded to detect and characterize PMR binding sites for $\mathrm{IP}_{4}$ which may play a critical role in salmon olfactory transduction. Binding sites for $\mathrm{IP}_{3}$ were subsequently detected in the endoplasmic reticulum-rich microsomal fraction.

\section{Materials and Methods}

2.1. Isolation of the Plasma Membrane Rich (PMR) and Microsomal Fractions. Atlantic salmon (Salmo salar) were raised under conditions of simulated natural photoperiod and temperature in the aquaculture facility of University of Rhode Island. Using a modification of a method devised originally for rainbow trout by Cagan and Zeiger [36], a plasma membrane rich (PMR) fraction was obtained from the olfactory rosettes as described previously [19]. Rosettes were pooled from ten salmon for each analysis. The microsomal fraction was isolated from the olfactory rosettes using the method of Kalinoski et al. [6]. For comparative purposes, PMR fractions and microsomal fractions were also prepared from salmon brain and rat brain. Concentrations of proteins were determined by the method of Bradford (BioRad Laboratories, Hercules, CA) with bovine serum albumin as a standard.

2.2. $I P_{3}$ Binding. Binding of $\left[{ }^{3} \mathrm{H}\right] \mathrm{IP}_{3}$ ([inositol-1- $\left.{ }^{3} \mathrm{H}\right] ; 21.0 \mathrm{Ci} /$ mmol; New England Nuclear, Boston, MA) was measured using conditions described by Kalinoski et al. [6] except that microsomal fractions $(100 \mu \mathrm{g}$ protein per assay) or PMR fractions (100-300 $\mu \mathrm{g}$ protein per assay) were from salmon olfactory rosettes or from salmon or rat brain. Digitonin $(50 \mu \mathrm{g} / \mathrm{mL})$ was added to permeabilize any membrane vesicles and insure that all binding sites are accessible [6]. The incubation buffer consisted of $110 \mathrm{mM} \mathrm{KCl}$, $1 \mathrm{mMEGTA} / 0.2 \mathrm{mM} \mathrm{CaCl}_{2}$ (free $\mathrm{Ca}^{2+}$ concentration = $20 \mathrm{nM}$ ), and $10 \mathrm{mM}$ HEPES, pH 7.4. Incubations were carried out for $30 \mathrm{~min}$ at $4^{\circ} \mathrm{C}$. Separation of bound and free $\left[{ }^{3} \mathrm{H}\right] \mathrm{IP}_{3}$ was achieved by rapidly filtering through Whatman GF/C filters and washing 3 times with assay buffer. Filters were extracted in scintillation cocktail for $4 \mathrm{hr}$, and the amount of associated radioactivity was determined by scintillation spectrometry. The amount of binding was determined in the absence (total binding) and presence (nonspecific binding) of excess $(120 \mu \mathrm{M})$ unlabeled InsP $\mathrm{P}_{3}$. Two concentrations of $\left[{ }^{3} \mathrm{H}\right] \mathrm{IP}_{3}$ (7 and $14 \mathrm{nM}$ ) were tested. The calculated difference between total and nonspecific binding was operationally defined as a specific binding.

2.3. $\mathrm{IP}_{4}$ Binding. The binding assay for $\left[{ }^{3} \mathrm{H}\right] \mathrm{IP}_{4}$ ([Inositol$\left.1-{ }^{3} \mathrm{H}\right] ; 21.0 \mathrm{Ci} / \mathrm{mmol}$; New England Nuclear, Boston, MA) was performed under conditions identical to those described by Challiss et al. [37]. The assay buffer consisted of $25 \mathrm{mM} \mathrm{CH}_{3} \mathrm{COONa}, 25 \mathrm{mM} \mathrm{KH}_{2} \mathrm{PO}_{4}, 5 \mathrm{mM} \mathrm{NaHCO}_{3}$, $1 \mathrm{mMEDTA}, \mathrm{pH} 5.0$, and the indicated concentrations of $\left[{ }^{3} \mathrm{H}\right] \mathrm{IP}_{4}$. Nonspecific binding was defined by the inclusion of $120 \mu \mathrm{M}$ unlabeled $\mathrm{IP}_{4}$. To characterize the binding specificity, competition assays were conducted with a minimum of three concentrations of other inositol polyphosphates $\left(\operatorname{Ins} \mathrm{P}_{x}\right): \operatorname{InsP}_{6}, \operatorname{Ins}(1,3,4,5,6) \mathrm{P}_{5}, \operatorname{Ins}(3,4,5,6) \mathrm{P}_{4}, \operatorname{Ins}(1,4,5,6) \mathrm{P}_{4}$, Ins $(1,3,4) \mathrm{P}_{3}$, Ins $(1,4,5) \mathrm{P}_{3}$, Ins $(1,4) \mathrm{P}_{2}$, and $\operatorname{Ins}(4,5) \mathrm{P}_{2}$ (all generously provided by Dr. Ching-Shih Chen, School of Pharmacy, University of Rhode Island). Reactions were initiated by the addition of PMR fraction ( $100 \mu \mathrm{g}$ protein), and samples were maintained at $4^{\circ} \mathrm{C}$ for $30 \mathrm{~min}$ with gentle rocking. Separation of bound and free $\left[{ }^{3} \mathrm{H}\right] \mathrm{IP}_{4}$ was achieved by rapidly filtering through Whatman GF/C filters and washing 3 times with assay buffer. Filters were extracted in scintillation cocktail for $4 \mathrm{hr}$, and radioactivities were determined.

Binding assays for both $\left[{ }^{3} \mathrm{H}\right] \mathrm{IP}_{3}$ and $\left[{ }^{3} \mathrm{H}\right] \mathrm{IP}_{4}$ were based on conditions optimized by others $([6,36]$, resp.). To rule out any effect of the different incubation conditions (most notably $\mathrm{pH}$ ) on conclusions regarding binding of $\left[{ }^{3} \mathrm{H}\right] \mathrm{IP}_{3}$ or $\left[{ }^{3} \mathrm{H}\right] \mathrm{IP}_{4}$, each was tested at the conditions that had been optimized for the other. As expected, binding was negligible when measured at nonoptimal conditions.

\section{Results}

3.1. $I P_{3}$ Binding. At a radioligand concentration of $7 \mathrm{nM}$, no specific binding of $\mathrm{IP}_{3}$ was detectable with the olfactory PMR fraction. At $14 \mathrm{nM}$ radioligand, $\mathrm{IP}_{3}$ binding to the olfactory PMR fraction was at the lower limit of detection in the assay (see data labeled $\mathrm{IP}_{3}-\mathrm{PMR}$ in Figure 1). Nonspecific binding accounted for almost $90 \%$ of the small amount of total binding of $\left[{ }^{3} \mathrm{H}\right] \mathrm{IP}_{3}$ to the PMR fraction. Similar results were obtained with a salmon brain PMR fraction, analyzed as a negative control. The specific binding of $\left[{ }^{3} \mathrm{H}\right] \mathrm{IP}_{3}$ corresponded to a maximum of $16 \mathrm{fmol}$ bound per $\mathrm{mg}$ olfactory PMR protein and $10 \mathrm{fmol}$ per $\mathrm{mg}$ salmon brain fraction.

In contrast, specific binding sites for $\left[{ }^{3} \mathrm{H}\right] \mathrm{IP}_{3}$ were readily detected in a microsomal (MS) preparation from salmon olfactory rosettes (see data labeled $\mathrm{IP}_{3}$-MS in Figure 1). In this preparation, specific binding accounted for at least 75\% of the total binding of $\left[{ }^{3} \mathrm{H}\right] \mathrm{IP}_{3}$ and corresponded to $1.2 \mathrm{pmol}$ $\mathrm{IP}_{3}$ bound per mg MS protein, a level nearly 100 times higher than the PMR fraction. This compares favorably to the level 


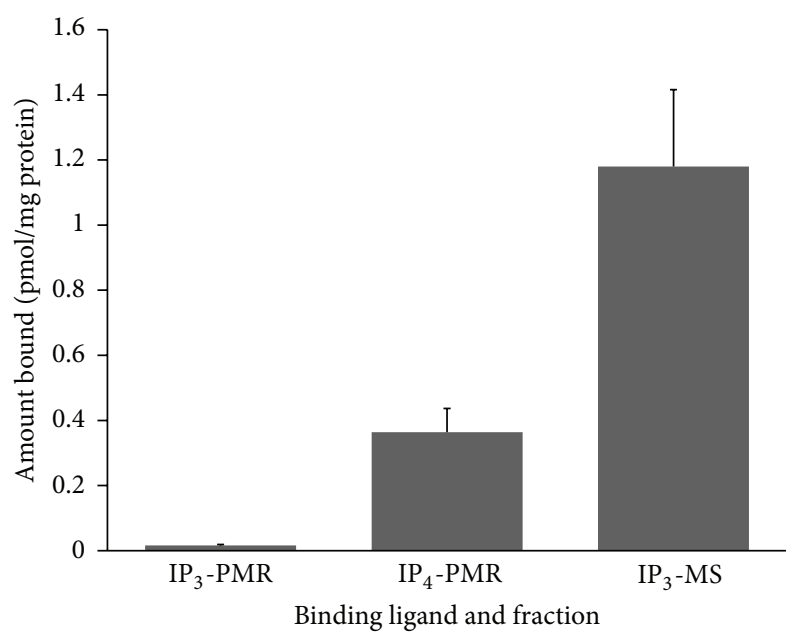

FIGURE 1: Initial screening of $\mathrm{IP}_{3}$ and $\mathrm{IP}_{4}$ binding sites in membrane fractions from salmon olfactory rosettes. The plasma membrane rich (PMR) fraction and a microsomal (MS) fraction were prepared from olfactory rosettes of Atlantic salmon. Specific binding of $\left[{ }^{3} \mathrm{H}\right] \mathrm{IP}_{3}$ was determined in incubations with $14 \mathrm{nM}\left[{ }^{3} \mathrm{H}\right] \mathrm{IP}_{3}$ in the presence and absence of excess unlabeled $\mathrm{InsP}_{3}$. Specific binding of $\mathrm{IP}_{4}$ to the $\mathrm{PMR}$ fraction is shown for comparison to $\mathrm{IP}_{3}$. The concentration of $\left[{ }^{3} \mathrm{H}\right] \mathrm{IP}_{4}$ in the reaction mixture was also $14 \mathrm{nM}$.

of $\mathrm{IP}_{3}$ binding measured in a rat brain microsomal fraction that was analyzed as a positive control.

3.2. $I P_{4}$ Binding. While $\mathrm{IP}_{3}$ binding to the salmon olfactory PMR fraction was at the lower limit for detection in our assay, binding sites for $\mathrm{IP}_{4}$ were readily detected and were present at high density (see data labeled $\mathrm{IP}_{4}-\mathrm{PMR}$ in Figure 1). At comparable ligand concentration (14 nM), the olfactory PMR fraction supported binding of $364 \mathrm{fmol} \mathrm{IP}_{4}$ per mg protein (contrasted with $16 \mathrm{fmol} \mathrm{IP}_{3}$ per mg protein). Nonspecific binding represented less than $20 \%$ of total binding. In a single trial with the microsomal preparation from salmon olfactory rosettes, specific binding of $\left[{ }^{3} \mathrm{H}\right] \mathrm{IP}_{4}$ was at the lower limit of detection (not shown). Thus, $\mathrm{IP}_{4}$ sites were readily detected in the PMR but not the microsomal fraction, a result opposite of that for $\mathrm{IP}_{3}$ binding.

Experiments performed with increasing concentrations of $\left[{ }^{3} \mathrm{H}\right] \mathrm{IP}_{4}$ demonstrated that specific binding was saturable (Figure 2). Scatchard analysis of the binding data (Figure 2, inset) yielded $83 \mathrm{nM}$ for the $K_{d}$ and $3811 \mathrm{fmol} / \mathrm{mg}$ protein for the $B_{\max }$ for $\mathrm{IP}_{4}$ binding to the olfactory PMR fraction.

To further characterize the specificity of $\mathrm{IP}_{4}$ binding to the olfactory PMR fraction, competition experiments were performed using $14 \mathrm{nM}\left[{ }^{3} \mathrm{H}\right] \mathrm{IP}_{4}$ and various other inositol polyphosphates $\left(\operatorname{InsP}_{x}\right)$ differing in degree and position of phosphorylation (Figure 3 ). If an analog competes with $\mathrm{IP}_{4}$, then binding will decrease as the concentration of the analog increased (Figure 3).

Ins $_{5}$ and $\mathrm{InsP}_{6}$ showed reasonably potent inhibition of $\left[{ }^{3} \mathrm{H}\right] \mathrm{IP}_{4}$ binding. Other $\mathrm{IP}_{4}$ analogs $\left(\operatorname{Ins}(3,4,5,6) \mathrm{P}_{4}\right.$ and Ins $\left.(1,4,5,6) \mathrm{P}_{4}\right)$ were intermediate in potency as inhibitors,

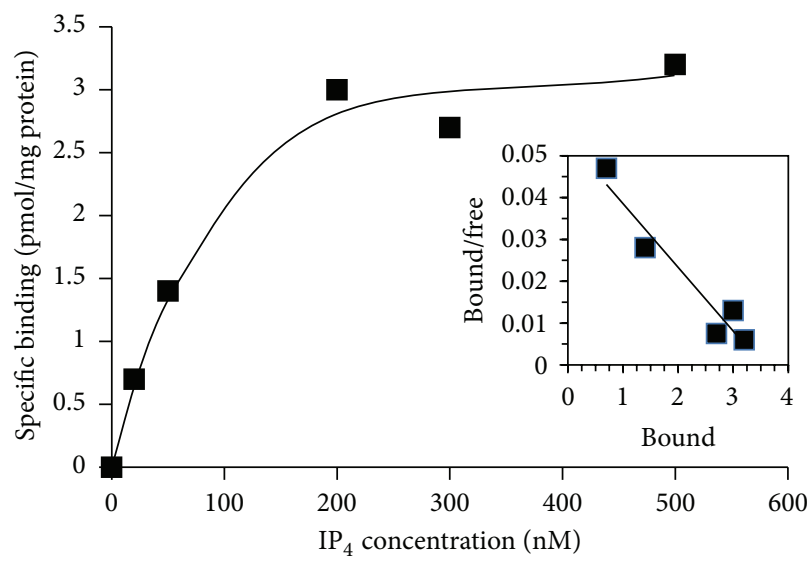

Figure 2: Saturation binding of $\left[{ }^{3} \mathrm{H}\right] \mathrm{IP}_{4}$ to a plasma membrane rich fraction from salmon olfactory rosettes. Specific binding of $\mathrm{IP}_{4}$ was determined at each of the $\mathrm{IP}_{4}$ concentrations shown. Results are averaged from a single experiment performed in duplicate using olfactory rosettes from 10 Atlantic salmon and are representative of the results of three independent experiments. The inset shows a Scatchard analysis of the binding of IP4 to the plasma membrane rich fraction. Binding data as in Figure 2 was transformed to estimate the $K_{d}$ and $B_{\max }$. The data fit a straight line $\left(R^{2}=0.93\right)$ indicative of a single class of binding sites.

while the $\mathrm{IP}_{3}$ analogs $\left(\operatorname{Ins}(1,3,4) \mathrm{P}_{3}\right.$ and $\left.\operatorname{Ins}(1,4,5) \mathrm{P}_{3}\right)$ showed little or no activity. Similarly, $\operatorname{Ins}(1,4) \mathrm{P}_{2}$ and $\operatorname{Ins}(4,5) \mathrm{P}_{2}$, the dephosphorylation products formed from the inactivation of Ins $(1,4,5) \mathrm{P}_{3}$, had no inhibitory effect on $\left[{ }^{3} \mathrm{H}\right] \mathrm{IP}_{4}$ binding when incubated at $10 \mu \mathrm{M}$ (data not included in Figure 3). From these competition assays, the effective concentration of analog giving $50 \%$ inhibition of $\left[{ }^{3} \mathrm{H}\right] \mathrm{IP}_{4}$ binding $\left(\mathrm{EC}_{50}\right)$ was estimated (Table 1$)$. From this analysis, the rank order for potency of inhibition to $\left[{ }^{3} \mathrm{H}\right] \mathrm{IP}_{4}$ binding was Ins $\mathrm{P}_{6}>\operatorname{Ins}(1,3,4,5,6) \mathrm{P}_{5}>\operatorname{Ins}(3,4,5,6) \mathrm{P}_{4}>\operatorname{Ins}(1,4,5,6) \mathrm{P}_{4}>$ $\operatorname{Ins}(1,3,4) \mathrm{P}_{3}=\operatorname{Ins}(1,4,5) \mathrm{P}_{3}$.

\section{Discussion}

Previous characterization of the PMR fraction showed high levels of the plasma membrane marker $\mathrm{Na}$, K-ATPase and binding sites for amino acid $[19,20]$ and bile acid [18] odors. This fraction had minimal contamination with endoplasmic reticulum as suggested by the absence of thapsigarginsensitive $\mathrm{Ca}^{2+}$-ATPase [35]. The low level of observed $\mathrm{IP}_{3}$ binding can also be considered as evidence of the lack of ER especially when compared to the microsomal fraction which is traditionally used as a source of endoplasmic reticulum and $\mathrm{IP}_{3}$ receptors [25]. A comparison of $\mathrm{IP}_{3}$ binding to the two subcellular fractions is consistent with the presence of $\mathrm{IP}_{3}$ receptors in endoplasmic reticulum rather than plasma membranes. This does not rule out the possibility that $\mathrm{IP}_{3}$ receptors would be detected at a higher level in isolated cilia [6] rather than the PMR fraction, but the low level of $\mathrm{IP}_{3}$ binding to the olfactory PMR fraction contrasts sharply with the high density of binding sites corresponding to odorant amino acid receptors $[19,20]$. Clearly, $\mathrm{IP}_{3}$ receptors do not 
TABLE 1: $\mathrm{EC}_{50}$ values for inhibition of $\mathrm{IP}_{4}$ binding by inositol polyphosphates.

\begin{tabular}{lc}
\hline Inositol polyphosphate & $\mathrm{EC}_{50}$ \\
\hline InsP $_{6}$ & $42.7 \mathrm{nM}$ \\
$\operatorname{Ins}(1,3,4,5,6) \mathrm{P}_{5}$ & $316 \mathrm{nM}$ \\
$\operatorname{Ins}(3,4,5,6) \mathrm{P}_{4}$ & $3.2 \mu \mathrm{M}$ \\
$\operatorname{Ins}(1,4,5,6) \mathrm{P}_{4}$ & $31.6 \mu \mathrm{M}$ \\
$\operatorname{Ins}(1,4,5) \mathrm{P}_{3}$ & $>100 \mu \mathrm{M}$ \\
$\operatorname{Ins}(1,3,4) \mathrm{P}_{3}$ & $>100 \mu \mathrm{M}$ \\
$\operatorname{Ins}(1,4) \mathrm{P}_{2}$ & No inhibition at $10 \mu \mathrm{M}$ \\
$\operatorname{Ins}(4,5) \mathrm{P}_{2}$ & No inhibition at $10 \mu \mathrm{M}$ \\
\hline
\end{tabular}

Concentrations of the competing inositol polyphosphate $\left(\operatorname{Ins}_{x}\right)$ effective in reducing $\left[{ }^{3} \mathrm{H}\right] \mathrm{IP}_{4}$ binding to $50 \%$ of the specific binding $\left(\mathrm{EC}_{50}\right)$ were derived from competition curves as shown in Figure 3. Incubations included $14 \mathrm{nM}$ $\left[{ }^{3} \mathrm{H}\right] \mathrm{IP}_{4}$.

colocalize with odorant receptors in this fraction. Thus, our initial hypothesis that $\mathrm{IP}_{3}$ binding sites would be abundant in the PMR fraction from the olfactory rosettes of Atlantic salmon was not supported by this study.

In contrast, $\mathrm{IP}_{4}$ binding sites were abundant in this PMR fraction, which was previously shown to support odorstimulated PLC activity $[17,18,20]$. Thus, it is an $\mathrm{IP}_{4}$ binding that colocalizes with odor receptors in the PMR fraction from salmon. Although the binding sites for $\mathrm{IP}_{4}$ appear in the PMR fraction with odor binding sites, we cannot confirm from this result alone that they appear together on the same membrane. In the only other olfactory system in which it has been characterized, $\mathrm{IP}_{4}$ gated a calcium channel in the lobster olfactory system [26]. If in salmon, the colocalization of odor and $\mathrm{IP}_{4}$ binding sites in the PMR fraction extends to a common membrane location, then an $\mathrm{IP}_{4}$ receptor could be an important downstream element in salmon olfactory transduction. The $\mathrm{pH}$ optimum and high affinity $K_{d}$ value for $\mathrm{IP}_{4}$ binding are similar to what has been reported in mammalian brain, but the profile for the competition by other InsP $\mathrm{P}_{x}$ is somewhat different [37]. The $B_{\max }$ for $\mathrm{IP}_{4}$ binding reflects a density of sites comparable to the density of $\mathrm{IP}_{3}$ binding sites in the olfactory plasma membrane of catfish $\left(B_{\max }=17.6 \mathrm{pmol} / \mathrm{mg}\right.$ protein from Kalinoski et al. [6]). The $K_{d}$ value for $\mathrm{IP}_{4}$ binding is much lower (i.e., the affinity is much higher) than the $K_{d}$ for $\mathrm{IP}_{3}$ binding sites in catfish $\left(K_{d}=1.1 \mu \mathrm{M}\right.$ from Kalinoski et al. [6]), which is consistent with the lower level of $\mathrm{IP}_{4}$ produced relative to $\mathrm{IP}_{3}$ [38].

In essentially all animal cells, $\mathrm{IP}_{3}$ is metabolized in a bifurcate pathway that includes phosphorylation by a 3-kinase to produce $\mathrm{IP}_{4}[28,39]$. Higher-order inositol polyphosphates are also produced in cells along with an array of dephosphorylation products. We included many of these inositol polyphosphates in competition analyses to further characterize the olfactory $\mathrm{IP}_{4}$ binding site. Among the inositol polyphosphates tested, $\mathrm{InsP}_{5}$ and $\mathrm{InsP}_{6}$ showed reasonably potent inhibition of $\left[{ }^{3} \mathrm{H}\right] \mathrm{IP}_{4}$ binding. These are formed by the sequential actions of specific kinases, are inhibitors of $\mathrm{IP}_{4} 3$-phosphatase and $\mathrm{IP}_{4} 5$-phosphatase [40], and are active in other cellular systems [41]. In contrast, $\operatorname{Ins}(1,3,4) \mathrm{P}_{3}, \operatorname{Ins}(1,4) \mathrm{P}_{2}$, and $\operatorname{Ins}(4,5) \mathrm{P}_{2}$ showed little or no

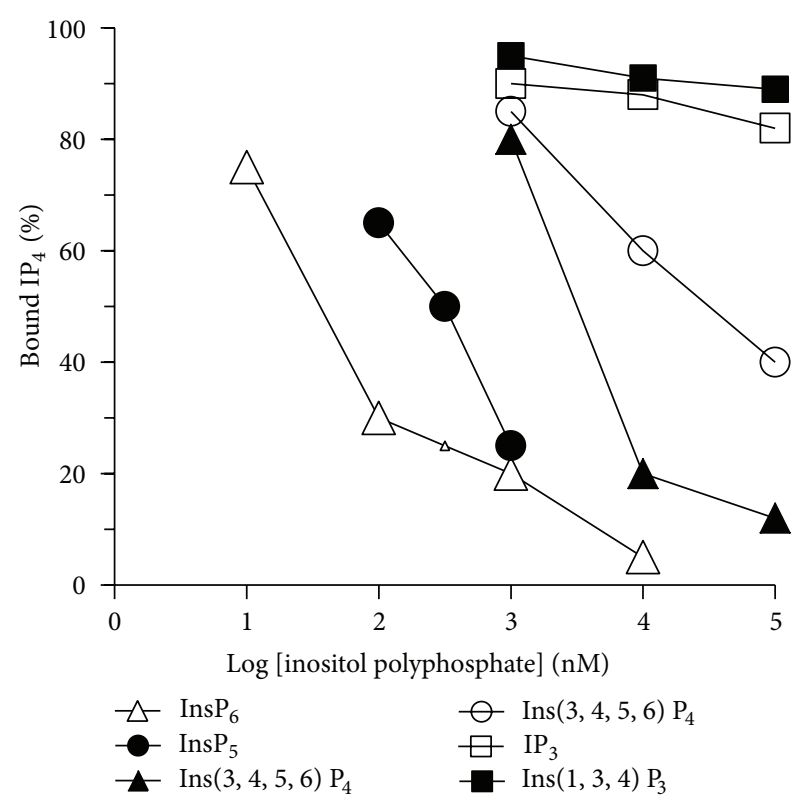

FIGURE 3: Inositol polyphosphate selectivity in competing for $\left[{ }^{3} \mathrm{H}\right] \mathrm{IP}_{4}$ binding to a PMR fraction from salmon olfactory rosettes. The relative amount of specific binding of $14 \mathrm{nM}\left[{ }^{3} \mathrm{H}\right] \mathrm{IP}_{4}$ was determined in the presence of at least three concentrations of different inositol polyphosphates $\left(\operatorname{Ins}_{x}\right.$ ): $\operatorname{Ins}_{6}$ (open triangles), Ins $(1,3,4,5,6) \mathrm{P}_{5}$ (filled circles), Ins $(3,4,5,6) \mathrm{P}_{4}$ (filled triangles), Ins $(1,4,5,6) \mathrm{P}_{4}$ (open circles), Ins $(1,3,4) \mathrm{P}_{3}$ (open squares) and Ins $(1,4,5) \mathrm{P}_{3}$ (filled squares). The level of specific binding of $\left[{ }^{3} \mathrm{H}\right] \mathrm{IP}_{4}$ in the absence of competitors was set at $100 \%$.

ability to interact with the $\mathrm{IP}_{4}$ site. This is not surprising because these are regarded as the products of inactivating phosphatases. Marginal inhibition of $\left[{ }^{3} \mathrm{H}\right] \mathrm{IP}_{4}$ binding by $\mathrm{IP}_{3}$ $\left(\operatorname{Ins}(1,4,5) \mathrm{P}_{3}\right)$ confirmed the independence of the $\mathrm{IP}_{4}$ and $\mathrm{IP}_{3}$ binding sites in this system and supported the conclusions from direct measurements of $\left[{ }^{3} \mathrm{H}\right] \mathrm{IP}_{3}$ binding at optimal $\mathrm{pH}$ that these sites are not present in the PMR fraction.

In summary, we found a unique $\mathrm{IP}_{4}$ binding site that colocalizes with odor receptors in a subcellular fraction derived from the olfactory system of Atlantic salmon. This is the first biochemical evidence of a putative membrane-bound $\mathrm{IP}_{4}$ receptor in a fish olfactory system. The exact plasma membrane location and the colocalization of odor receptors and putative $\mathrm{IP}_{4}$ receptors in the same plasma membrane remain to be shown. In the only other olfactory system in which it has been studied, electrophysiological studies have demonstrated that $\mathrm{IP}_{4}$ gates a calcium channel and helps regulate $\mathrm{Ca}^{2+}$ entry into lobster olfactory neurons [26], a similar role to that ascribed to $\mathrm{IP}_{3}$ in lobster [27], catfish [6], and carp [14]. This provides the only context with which to interpret the significance of finding $\mathrm{IP}_{4}$ binding sites in membranes of the salmon olfactory system and to begin to suggest that $\mathrm{IP}_{4}$ rather than (or in addition to) $\mathrm{IP}_{3}$ may be a key downstream element for olfactory signal transduction in Atlantic salmon. 


\section{Acknowledgments}

The authors thank Dr. Terrance Bradley for providing the Atlantic salmon used in this study and Dr. Ching-Shih Chen for providing the inositol phosphate analogs. Initial portions of this paper were supported by the University of Rhode Island. The authors acknowledge the advice and assistance of Dr. Jian Wang and Dr. Chun-Shiang Chung with the brain fractions and Lee-Ju Cheng with $\mathrm{IP}_{3}$ binding assays. The authors also thank Dr. Karl Hartman for helpful discussions and suggestions.

\section{References}

[1] D. Schild and D. Restrepo, "Transduction mechanisms in vertebrate olfactory receptor cells," Physiological Reviews, vol. 78, no. 2, pp. 429-466, 1998.

[2] R. Elsaesser and J. Paysan, "Morituri te salutant? Olfactory signal transduction and the role of phosphoinositides," Brain Cell Biology, vol. 34, no. 1-2, pp. 97-116, 2005.

[3] B. W. Ache, "Odorant-specific modes of signaling in mammalian olfaction," Chemical Senses, vol. 35, no. 7, pp. 533-539, 2010.

[4] K. Ukhanov, E. A. Corey, D. Brunert, K. Klasen, and B. W. Ache, "Inhibitory odorant signaling in mammalian olfactory receptor neurons," Journal of Neurophysiology, vol. 103, no. 2, pp. 1114$1122,2010$.

[5] R. C. Bruch, "Phosphoinositide second messengers in olfaction," Comparative Biochemistry and Physiology B, vol. 113, no. 3, pp. 451-459, 1996.

[6] D. L. Kalinoski, S. B. Aldinger, A. G. Boyle et al., "Characterization of a novel inositol 1,4,5-trisphosphate receptor in isolated olfactory cilia," Biochemical Journal, vol. 281, no. 2, pp. 449-456, 1992.

[7] C. Abogadie Fe. C., R. C. Bruch, and A. I. Farbman, "Gprotein subunits expressed in catfish olfactory receptor neurons," Chemical Senses, vol. 20, no. 2, pp. 199-206, 1995.

[8] F. C. Abogadie, R. C. Bruch, R. Wurzburger, F. L. Margolis, and A. I. Farbman, "Molecular cloning of a phosphoinositidespecific phospholipase C from catfish olfactory rosettes," Molecular Brain Research, vol. 31, no. 1-2, pp. 10-16, 1995.

[9] R. C. Bruch, J. Kang, M. L. Moore Jr., and K. F. Medler, "Protein kinase $\mathrm{C}$ and receptor kinase gene expression in olfactory receptor neurons," Journal of Neurobiology, vol. 33, no. 4, pp. 387-394, 1997.

[10] C. Dellacorte, D. Restrepo, B. P. M. Menco, I. Andreini, and D. L. Kalinoski, " $\mathrm{G} \alpha_{q} / \mathrm{G} \alpha_{11}$ : immunolocalization in the olfactory epithelium of the rat (rattus rattus) and the channel catfish ict alurus punctatus," Neuroscience, vol. 74, no. 1, pp. 261-273, 1996.

[11] K. F. Medler, H. N. Tran, J. M. Parker, J. Caprio, and R. C. Bruch, "Metabotropic glutamate receptor expression in olfactory receptor neurons from the channel catfish, Ictalurus punctatus," Journal of Neurobiology, vol. 35, no. 1, pp. 94-104, 1998.

[12] K. F. Medler and R. C. Bruch, "Protein kinase $\mathrm{C} \beta$ and $\delta$ selectively phosphorylate odorant and metabotropic glutamate receptors," Chemical Senses, vol. 24, no. 3, pp. 295-299, 1999.

[13] A. Hansen, S. H. Rolen, K. Anderson, Y. Morita, J. Caprio, and T. E. Finger, "Correlation between olfactory receptor cell types and function in the channel catfish," Journal of Neuroscience, vol. 23, no. 28, pp. 9328-9339, 2003.
[14] H. Cadiou, I. Sienaert, S. Vanlingen, J. B. Parys, G. Molle, and H. Duclohier, "Basic properties of an inositol 1,4,5-trisphosphategated channel in carp olfactory cilia," European Journal of Neuroscience, vol. 12, no. 8, pp. 2805-2811, 2000.

[15] H. Cadiou and G. Molle, "Adenophostin A and imipramine are two activators of the olfactory inositol 1,4,5-trisphosphate-gated channel in fish olfatory cilia," European Biophysics Journal, vol. 32, no. 2, pp. 106-112, 2003.

[16] W. C. Michel, M. J. Sanderson, J. K. Olson, and D. L. Lipschitz, "Evidence of a novel transduction pathway mediating detection of polyamines by the zebrafish olfactory system," Journal of Experimental Biology, vol. 206, no. 10, pp. 1697-1706, 2003.

[17] Y. H. Lo, T. M. Bradley, and D. E. Rhoads, "Stimulation of $\mathrm{Ca}^{2+}$-regulated olfactory phospholipase C by amino acids," Biochemistry, vol. 32, no. 46, pp. 12358-12362, 1993.

[18] Y. H. Lo, S. L. Bellis, L. J. Cheng, J. Pang, T. M. Bradley, and D. E. Rhoads, "Signal transduction for taurocholic acid in the olfactory system of Atlantic salmon," Chemical Senses, vol. 19, no. 5, pp. 371-380, 1994.

[19] Ying Har Lo, T. M. Bradley, and D. E. Rhoads, "L-Alanine binding sites and $\mathrm{Na}^{+}, \mathrm{K}^{+}$-ATPase in cilia and other membrane fractions from olfactory rosettes of Atlantic salmon," Comparative Biochemistry and Physiology B, vol. 98, no. 1, pp. 121-126, 1991.

[20] J. Pang, Y. H. Lo, J. M. Chandlee, and D. E. Rhoads, "A subtype of the metabotropic glutamate receptor family in the olfactory system of Atlantic salmon," FEBS Letters, vol. 354, no. 3, pp. 301304, 1994.

[21] A. Wickens, D. May, and M. Rand-Weaver, "Molecular characterisation of a putative Atlantic salmon (Salmo salar) odorant receptor," Comparative Biochemistry and Physiology B, vol. 129, no. 2-3, pp. 653-660, 2001.

[22] J. P. Dukes, R. Deaville, D. Gottelli, J. E. Neigel, M. W. Bruford, and W. C. Jordan, "Isolation and characterisation of main olfactory and vomeronasal receptor gene families from the Atlantic salmon (Salmo salar)," Gene, vol. 371, no. 2, pp. 257267, 2006.

[23] K. A. Johnstone, K. L. Ciborowski, K. P. Lubieniecki et al., "Genomic organization and evolution of the vomeronasal type 2 receptor-like (OlfC) gene clusters in atlantic salmon, Salmo salar," Molecular Biology and Evolution, vol. 26, no. 5, pp. 11171125, 2009.

[24] J. P. Dukes, R. Deaville, M. W. Bruford, A. F. Youngson, and W. C. Jordan, "Odorant receptor gene expression changes during the parr-smolt transformation in Atlantic salmon," Molecular Ecology, vol. 13, no. 9, pp. 2851-2857, 2004.

[25] K. Mikoshiba, " $\mathrm{IP}_{3}$ receptor/ $\mathrm{Ca}^{2+}$ channel: from discovery to new signaling concepts," Journal of Neurochemistry, vol. 102, no. 5, pp. 1426-1446, 2007.

[26] D. A. Fadool and B. W. Ache, "Inositol 1,3,4,5-tetrakisphosphate-gated channels interact with inositol 1,4,5-trisphosphategated channels in olfactory receptor neurons," Proceedings of the National Academy of Sciences of the United States of America, vol. 91, no. 20, pp. 9471-9475, 1994.

[27] S. D. Munger, R. A. Gleeson, H. C. Aldrich, N. C. Rust, B. W. Ache, and R. M. Greenberg, "Characterization of a phosphoinositide-mediated odor transduction pathway reveals plasma membrane localization of an inositol 1,4,5- trisphosphate receptor in lobster olfactory receptor neurons," The Journal of Biological Chemistry, vol. 275, no. 27, pp. 2045020457, 2000. 
[28] R. F. Irvine, A. J. Letcher, J. P. Heslop, and M. J. Berridge, "The inositol tris/tetrakisphosphate pathway-demonstration of Ins(1,4,5)P3 3-kinase activity in animal tissues," Nature, vol. 320, no. 6063, pp. 631-634, 1986.

[29] M. J. Berridge and R. F. Irvine, "Inositol phosphates and cell signalling," Nature, vol. 341, no. 6239, pp. 197-205, 1989.

[30] S. K. Joseph and J. R. Williamson, "Inositol polyphosphates and intracellular calcium release," Archives of Biochemistry and Biophysics, vol. 273, no. 1, pp. 1-15, 1989.

[31] A. N. Malviya and C. Klein, "Mechanism regulating nuclear calcium signaling," Canadian Journal of Physiology and Pharmacology, vol. 84, no. 3-4, pp. 403-422, 2006.

[32] Y. H. Huang, J. A. Grasis, A. T. Miller et al., "Positive regulation of Itk PH domain function by soluble $\mathrm{IP}_{4}$," Science, vol. 316, no. 5826, pp. 886-889, 2007.

[33] A. Galvita, D. Grachev, T. Azarashvili et al., "The brainspecific protein, $\mathrm{p} 42^{I P 4}$ (ADAP 1) is localized in mitochondria and involved in regulation of mitochondrial $\mathrm{Ca}^{2+}$, Journal of Neurochemistry, vol. 109, no. 6, pp. 1701-1713, 2009.

[34] T. Azarashvili, R. Stricker, and G. Reiser, "The mitochondria permeability transition pore complex in the brain with interacting proteins-promising targets for protection in neurodegenerative diseases," Biological Chemistry, vol. 391, no. 6, pp. 619$629,2010$.

[35] Y. H. Lo, T. M. Bradley, and D. E. Rhoads, "Ca ${ }^{2+}$-ATPase," Biochemistry, vol. 32, pp. 12358-12362, 1994.

[36] R. H. Cagan and W. N. Zeiger, "Biochemical studies of olfaction: binding specificity of radioactively labeled stimuli to an isolated olfactory preparation from rainbow trout (Salmo gairdneri)," Proceedings of the National Academy of Sciences of the United States of America, vol. 75, no. 10, pp. 4679-4683, 1978.

[37] R. A. J. Challiss, A. L. Willcocks, B. Mulloy, B. V. L. Potter, and S. R. Nahorski, "Characterization of inositol 1,4,5-trisphosphateand inositol 1,3,4,5-tetrakisphosphate-binding sites in rat cerebellum," Biochemical Journal, vol. 274, no. 3, pp. 861-867, 1991.

[38] P. M. Smith, A. R. Harmer, A. J. Letcher, and R. F. Irvine, "The effect of inositol 1,3,4,5-tetrakisphosphate on inositol trisphosphate-induced $\mathrm{Ca}^{2+}$ mobilization in freshly isolated and cultured mouse lacrimal acinar cells," Biochemical Journal, vol. 347, no. 1, pp. 77-82, 2000.

[39] M. M. Nalaskowski, U. Bertsch, W. Fanick, M. C. Stockebrand, H. Schmale, and G. W. Mayr, "Rat inositol 1,4,5-trisphosphate 3kinase C is enzymatically specialized for basal cellular inositol trisphosphate phosphorylation and shuttles actively between nucleus and cytoplasm," The Journal of Biological Chemistry, vol. 278, no. 22, pp. 19765-19776, 2003.

[40] A. Hoer and E. Oberdisse, "Inositol 1,3,4,5,6-pentakisphosphate and inositol hexakisphosphate are inhibitors of the soluble inositol 1,3,4,5-tetrakisphosphate 3-phosphatase and the inositol 1,4,5-trisphosphate/1,3,4,5-tetrakisphosphate 5-phosphatase from pig brain," Biochemical Journal, vol. 278, no. 1, pp. 219-224, 1991.

[41] K. G. Oliver, J. W. Putney, J. F. Obie, and S. B. Shears, "The interconversion of inositol 1,3,4,5,6-pentakisphosphate and inositol tetrakisphosphates in AR4-2J cells," The Journal of Biological Chemistry, vol. 267, no. 30, pp. 21528-21534, 1992. 

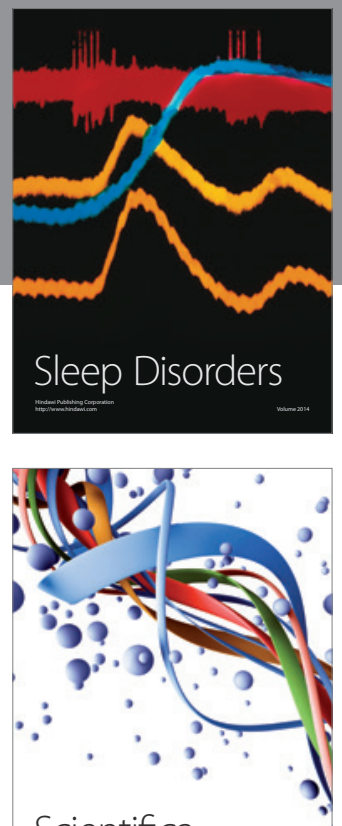

Scientifica
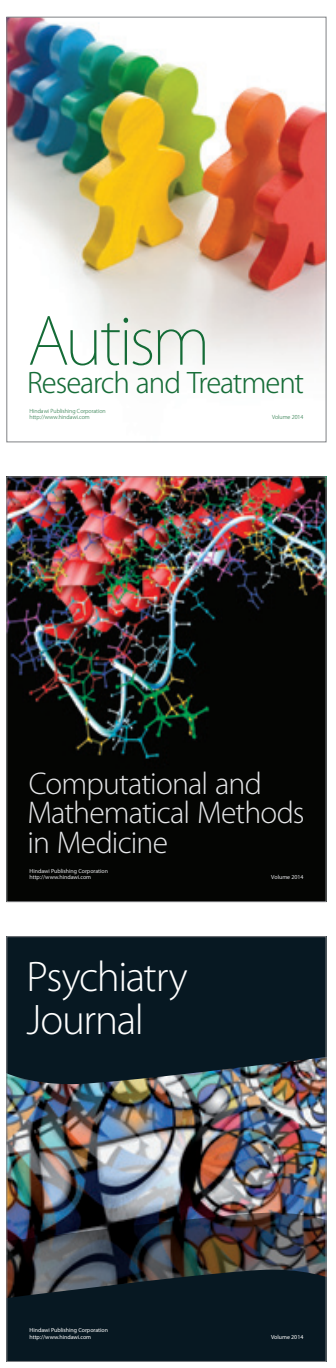
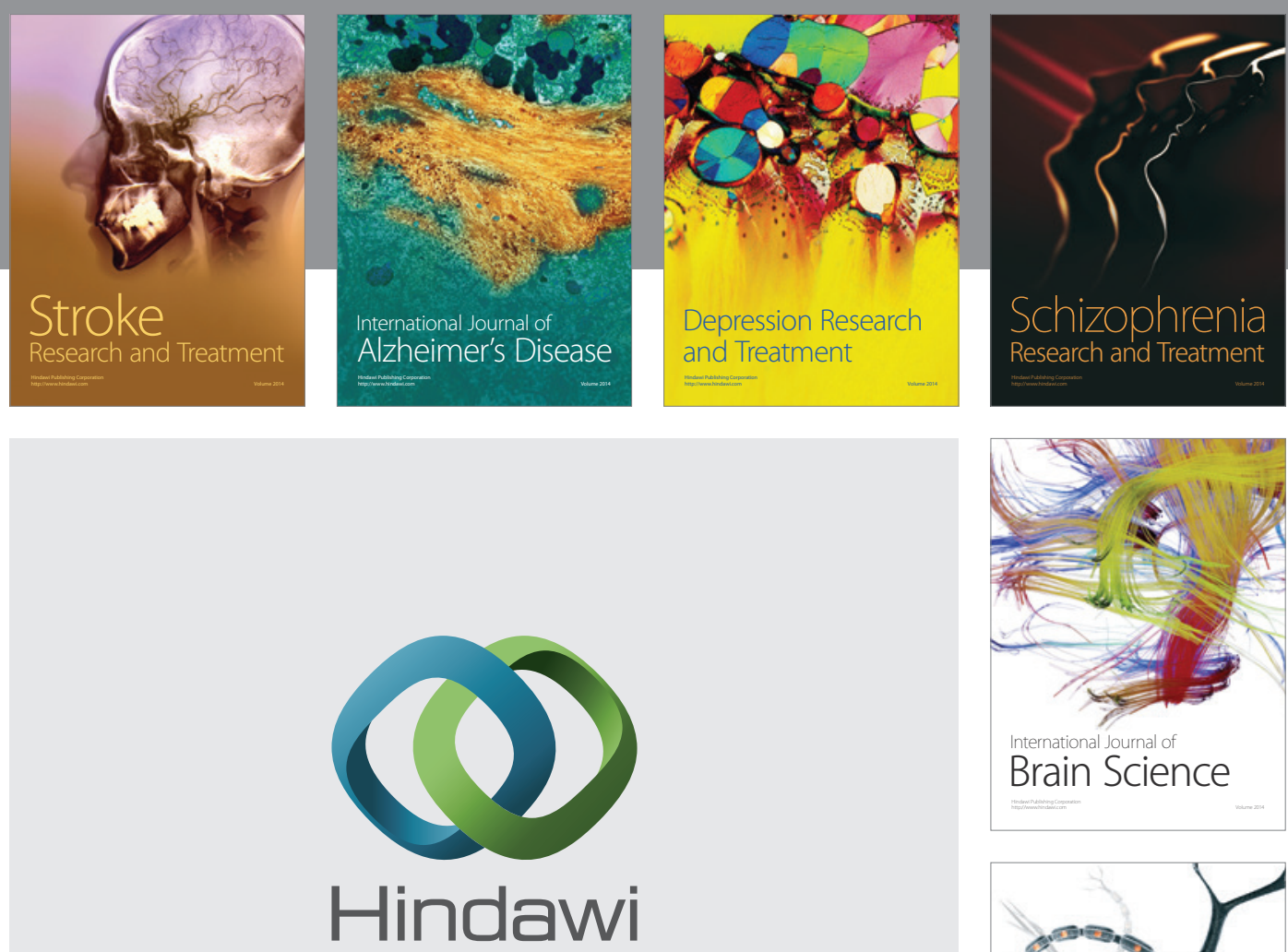

Submit your manuscripts at

http://www.hindawi.com
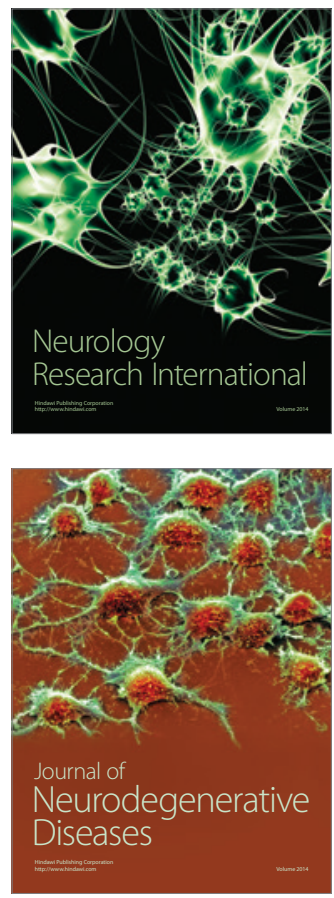

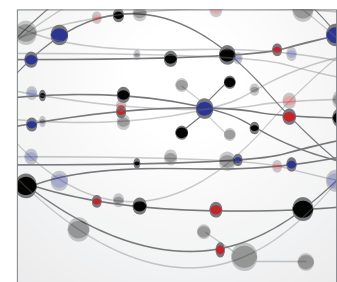

The Scientific World Journal
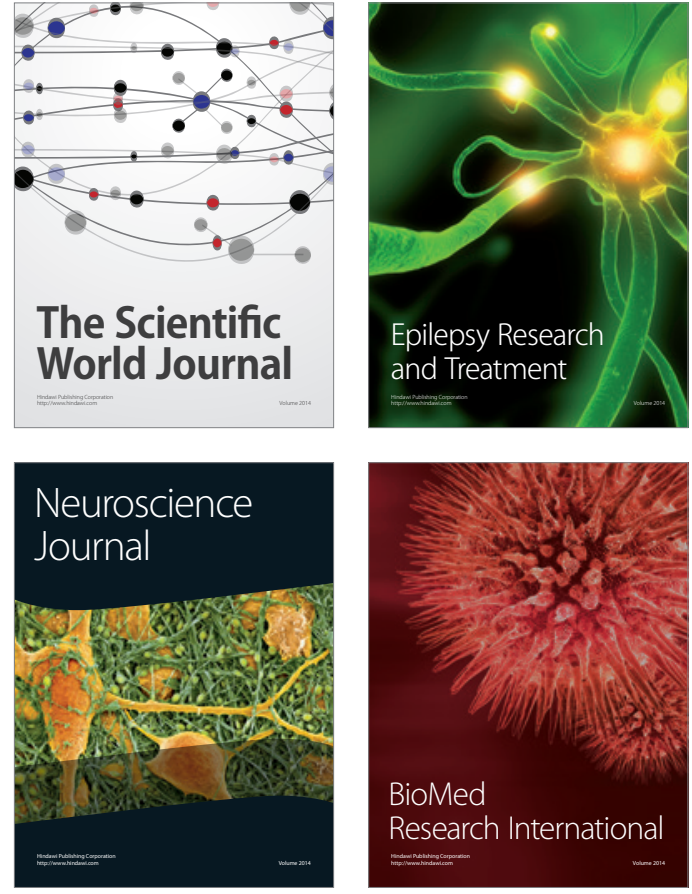

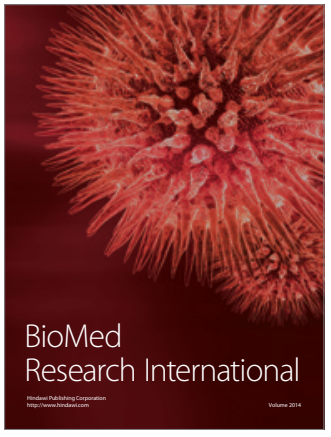

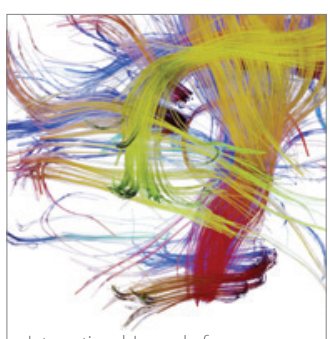

Brain Science

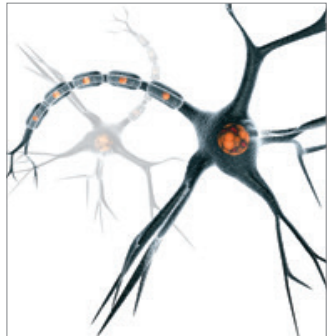

Neural Plasticity
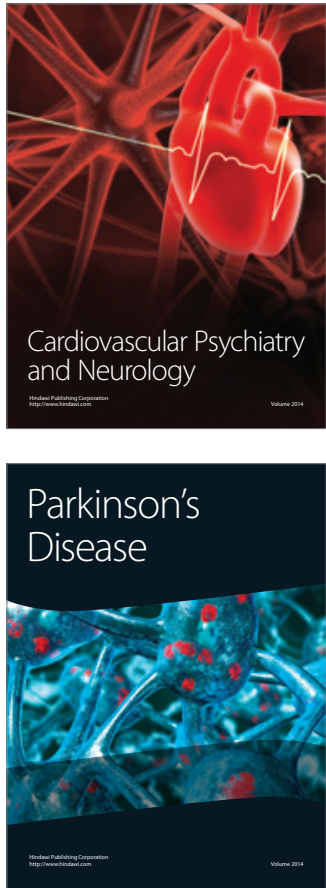